\title{
Analysis of the Effect of Scamper Education Program on five-year-old children's creativity
}

\author{
Nazan Kaytez ${ }^{1}$ \\ Abide Güngör Aytar ${ }^{2}$
}

\begin{abstract}
This study is conducted with a view to examine the effect of Scamper Education Program on fiveyear-old children's creativity. Study group of the research consists of a total of 40 children including an experimental group of 20 five-year-old children and a control group of 20 children attending kindergarten affiliated to Directorate of National Education in Çankırı city center. In the research, an experimental model with pretest, posttest, follow-up test control group was used. Children in the experimental group were applied with Scamper Education Program two days a week for a period of eight weeks. The children in the control group continued their own training programs. As the data collection tool in the study, "Personal Information Form" and "Creative Behavior and Personality Traits Scale were used. Single factor covariance analysis (ANCOVA) and $t$ test were used for data analysis. As a result of the research, it has been determined that there is a significant difference between creativity score averages of children in the experiment and control group $(\mathrm{p}<0.001)$, there is no significant differences between post-test and follow-up test score averages of children in the experiment group $(p>0.05)$. This result shows that Scamper Education Program provided to the experimental group is effective in creativity of children.
\end{abstract}

Keywords: Preschool period; creative behavior; creative personality; scamper technique; scamper education program.

\section{Introduction}

Preschool period is a period when children are open to creativity at most (Levine, 2002). San (2004) attributed children's openness to creativity in this period to the fact that there is a lack of stereotyped social pressure and children are more free during this period. According to Gander and Gardiner (2007), each child is born with a creative potential, and preschool period is critical in the development of creativeness. In preschool period, children begin to organize information in a creative way and their dream world is very rich. During this period, children constantly wonder, ask questions, investigate, compare, explore and use their mental abilities to create a new product. Therefore, making use of this period effectively is important in terms of raising happy and creative individuals (Rein and Rein, 2000).

Many factors are effective in making good use of preschool period. The first among these factors is the parent factor. Creativity emerges in a family environment with healthy parents and children interaction (Godel, 2006). According to Brown and Johnson (2008), the foundation of future characteristics of children such as creative personality is composed of the family and the environment from the birth. According to Lamm and Keller (2007), for the development of

\footnotetext{
${ }^{1}$ Assist. Prof., Çankırı Karatekin University, Department of Child Development, nznunal@hotmail.com

2 Prof. Dr., Gazi University, Department of Early Childhood and Education, abidegungor@gmail.com
} 
creativity in children, parents should motive the child correctly with their attitudes and behaviors, and they should offer experiences suitable for their level of interest, skill and development.

Besides, effective preschool education offered to children is critical in development of creativity in children. Effective preschool education consists of components such as educational environment, education program and teacher supporting creativity (Bee and Boyd, 2009). Teacher attitude and education programs are of great importance in the formation of conditions favorable to the development of creativity in educational environments (Bilhan, 2007). Teacher must be a person who can think life-wide with a developed problem-solving skill; who is open to creativity, innovativeness, empathy and communication; who can be a correct role model for children; who knows well children's developmental characteristics, their interests and needs; and who can prepare the right training program accordingly. That is because creativity and natural curiosity in children can be revealed with a training program established using various techniques and methods suitable for children's developmental level (Alyazad, 2014).

One of the various methods and techniques supporting creativity in children is the scamper technique. Literally, the word, scamper, means to rush, to jump and to run (Osborn, 1993). Proposed by Osborne (1993) and developed by Eberle (1997), scamper is the series of thinking directed towards an object, idea, event, situation, problem etc. The basis of Scamper is based on brainstorming techniques. According to Osborne (1993), scamper is the systematized version of brainstorming technique. In the scamper technique, brainstorming is carried out in the form of specific steps. The purpose of these steps is to prevent disintegration of the subject or circling around a certain idea. At each step, participants are asked some questions and stimuli is sent to individual to think effectively. Thus, individual's systematic thinking is aimed (Hayes, 2004).Despite seen as restricting participants, scamper steps lead participants to think from different angles with several questions being asked during the implementation stage (Buser, Buser, Gladding and Wilkerson, 2011).

Because scamper is a fun and easily applicable technique, it can easily be used to develop creativity in children even during preschool period (Eberle, 1997). With preschool period children, scamper technique is used on an object, brainstorming is conducted with children about the object and this object is changed and developed (Y1ldiz, 2011). In addition, fairy tales and stories are created with children, new characters are added-removed in these fairy tales, and role playing is carried out (Yildiz and Israel, 2001). Scamper technique can be used very easily with learning methods such as drama, collaborative learning etc. or with self-study in classroom (İslim, 2009).

Scamper studies carried out during preschool period help students in changing and combining their thoughts and encourage them towards creative thinking (Jagiello, 2012). In particular, various question patterns constituting these scamper steps enable children to think differently; develop their problem-solving skills; encourage them to make discoveries; allow them to produce ideas and to practice accordingly; and teach them to destroy stereotypic ideas (Yağc1, 2012).

Analyzing studies conducted relating to the scamper technique aimed at developing creativity in children, it has been determined that there are limited number of researches conducted on scamper during preschool period either at home or abroad, and scamper technique is mostly discussed among primary school students (Yağc1, 2012; İslim, 2009; Majid et al. 2003; Toraman and Altun, 2013), high school students (Jelena, Apple, Toby and Tong, 2014), university students (Çelikler and Harman, 2015) and adults (Buser et al., 2011; Alyazad, 2014; Animasahun, 2014; Moreno et al., 2014). 
Analyzing studies conducted on the effects of education programs on creativity of preschool period children, it has been observed that studies are mainly conducted on effects of drama training (CanYaşar, 2009; Erkan, 2005; Yeh, Yeh, Li and Pen, 2006), music education (Aral, Köksal-Akyol and Sı̆̆ırtmaç, 2006; Chronopoulou and Riga, 2012), movement education (Jamali, Kazemi and Shahbazi, 2012; Zachopoulou, Trevlas and Konstadinidou, 2006), science education (Mirzadie et al., 2009), montessori (Şahintürk, 2012) and game-based education (Garaigordobil and Berrueco, 2011). Therefore, this study is considered important in terms of developing scamper education programs suitable for interest and needs of five-year-old children during preschool period, and in terms of examining whether scamper education program is effective in children's creative thinking. With reference to this idea, it is aimed to develop scamper education programs suitable for interests and needs of five-year-old children and to analyze effects of the program on children's creativity.

\section{Method}

\section{Research model}

In the study, with a view to analyze the effects of the Scamper Education Program on five-yearsold children's levels of creativity, experimental model with pretest, posttest, control group was used. Experimental model is a technique applied in controlled environments to examine the effect of the change in one or more independent variables on the dependent variable with a view to determine cause-effect relationships. In every study carried out with experimental model, there is always a comparison (Büyüköztürk, 2014). In this research model, dependent variable is "levels of creativity" of five-year-old children, and independent variable is "Scamper Education Program".

\section{Study Group}

In the study, participants consist of five-year-old children attending a total of six independent kindergartens affiliated to the Directorate of National Education in Çankırn city center. In accordance with opinions of kindergarten school administrators, two schools were selected as located in similar socio-cultural environment and those providing half-day training. With simple random sampling method, a school experimental group (20 children) from one school and a control group (20 children) from another school were determined. In the study, it is determined that $60 \%$ of children in the experimental group are girls, $40 \%$ of them are boys; and $50 \%$ of children in the control group are boys and $50 \%$ of them are girls. The majority of children in the experimental and control groups included in the study were found to be the first child (experimental: 40\%; control: 45\%) and have one sibling (experimental: $70 \%$; control: up to $60 \%$ ). Analyzing the duration of preschool education attendance, it has been determined that $40.0 \%$ of children in the experimental group attended preschool education at most for 7-12 months, and $\% 30$ of children in the control group attended preschool education for 13-18 months.

\section{Data Collection Tools}

"Personal Information Form" was used to determined demographic characteristics of children in experimental and control groups of the research; and "Creative Behavior and Personality Traits Scale" was used to determine effects of the applied program on creativity of children.

In the Personal Information Form, there are questions related to child's gender, birth order, number of siblings and duration of preschool education attendance.

Creative Behavior and Personality Traits Scale was developed by Garaigordobil and Berrueco (2007) to measure creative behaviors and personality traits in preschool period children, and adapted into Turkish and validity-reliability study was applied by Kaytez and Güngör-Aytar (2015). The scale was filled by children's teacher to determine creative behaviors and personality traits of 5-6 year-old children. It is determined that regression coefficients obtained a result of the 
confirmatory factor analysis vary between 0.40 and 0.70 , and t values are above the critical value which is 1.96 , obtained fit indices are $\chi^{2}=645.13, \mathrm{sd}=350.61, \mathrm{X}^{2} / \mathrm{sd}=1.84, \mathrm{RMSEA}=0.064$ $\mathrm{CFI}=0.92$, NNFI $=0.91$ and NFI $=0.91$, and the scale consists of 15 items and single dimension. It is revealed that item selectivity of the scale varies between 0.46 and 0.78 , Cronbach's alpha value is 0.94 , and test-retest correlation coefficient is 0.82 . The scale is graded in the form of $0=$ none; 1 = low; 2 = high; 3 = very high; interpretation is applied over total score. There is no reverse-coded item. The lowest score that can be obtained from the scale is 0 , the highest score is 45. High score obtained from the scale indicates a high level of creative behavior and personality traits.

Developing Scamper Education Program: Scamper Education Program aims to foster creativity of five-year-old children. For this purpose, an 8-week Scamper Education Program consisting of 16 activities were prepared. Prior to preparation of the program, field literature on creativity and Scamper was scanned, and various education programs on the subject were analyzed (Alyazad, 2014; Animasahun, 2014; Aral, Köksal-Akyol and Sı̆̆ırtmaç, 2006; Buser et al., 2011; Can-Yaşar, 2009; Chronopoulou and Riga, 2012; Çelikler and Harman, 2015; Erkan, 2005; Garaigordobil and Berrueco, 2011; İslim, 2009; Jamali, Kazemi and Shahbazi, 2012; Jelena, Apple, Toby and Tong, 2014; Majid et al., 2003; Mirzadie et al., 2009; Moreno et al. 2014; Şahintürk, 2012; Toraman and Altun, 2013; Yağc1, 2012; Yeh, Yeh, Li and Pen, 2006; Zachopoulou, Trevlas and Konstadinidou, 2006). In the process of preparing the program, the Ministry of Education, Preschool Educational Program (2013) was used, acquisitions and indicators towards supporting creativity of children were determined. Acquisitions and indicators were selected taking into account the development of five-year-old children. While determining content of the program, physical conditions of the place where the application would be applied, and interests and needs of five-year-old children were taken into consideration. Prepared program was presented for opinions of a total of seven academics who were experts in the field of preschool and child development fields for the purpose of evaluation. Experts evaluated the number of activities in the prepared education program, suitability of the program to developmental level of five-year-old children, suitability of used materials, harmony of activities with each other and whether they support each other, level of suitability to interest and appreciation of preschool period children, state of making the child active, applicability in preschool education environment and state of whether the program contained scamper technique. In accordance with opinions of experts, necessary adjustments are made and the Scamper Education Program was made ready for implementation. The activities were implemented in the form of about 1 hour and 2 days a week. Techniques such as dramatization and storytelling were used during activities, and games played were repeated based on children's interest. Post-activity assessment was made children were given the opportunity to explain their thoughts and feelings.

\section{Data Collection Method}

In this section, the implementation of pretests, educational program, posttest and follow-up test is explained.

\section{Implementation of Pretests}

One week before the application started, teachers of children included in the research were handed out with "Creative Behavior and Personality Traits Scale", a brief description about the scale was given, and teachers were asked to fill the scale for each child in their classrooms. Pretests were collected from teachers 1 week after their distribution. 

children's creativity. Journal of Human Sciences, 13(3), NNN-NNN. doi:10.14687/jhs.v13i3.4037

\section{Implementation of Education Programs}

Before implementation of the program, Çankırı Provincial Directorate of National Education and kindergarten administrator were interviewed, and necessary permits were obtained. In addition, teacher of the class that constitutes the experimental group of the research was interviewed, information was provided about objective, content and training process of the program. After the implementation of pretests, children in the experimental group $(n=20)$ were applied with Scamper Education Program in mornings (9.00-10.00) two days a week. Applications were carried out in classroom environment and schoolyard where children continuously received education. The researcher, before the education to be applied to the experimental group, organized an educational environment for each event accordingly. At the end of activities, children were asked open-ended questions, and assessment was made (for instance, how can we walk with a single shoe? How would it be like if animals wore shoes? etc.). Photographs of products obtained from the activities were taken. During the process of education, children's participation states were monitored, and there were not any problems on attendance. Children in the control group were not applied with Scamper Education Program; these children continued their current education.

\section{Implementation of Posttest}

After completion of implementation of the Education Program, "Creative Behavior and Personality Traits Scale" was applied again to teachers of children in experimental and control groups and teachers were asked to fill the scale for each child in their classrooms.

\section{Implementation of Follow-up Test}

With a view to determine whether the education program applied on children in experimental group was permanent, the researcher applied "Creative Behavior and Personality Traits Scale" on teachers 4 weeks after the last test.

\section{Analysis of data}

Independent samples t-test was used for the analysis of pretest score averages of children in experimental and control groups in the research; single factor analysis of covariance (ANCOVA) was used in pretest-posttest comparisons applied to test effect of Scamper Education Program since the condition for homogeneousness of variances and regression trends was met; on the other hand, paired samples t-test was used to determine whether there was a significant difference between posttest and follow-up test scores of children.

\section{Findings}

Findings obtained from the study conducted to determine effects of Scamper Education Program on five-year-old children's level of creativity are presented in the tables.

Table 1. T-Test Results on Pretest Score Averages of Children in Experimental and Control Group Obtained from Creative Behavior and Personality Traits Scale

\begin{tabular}{llllllll}
\hline Scale & Group & $\mathbf{n}$ & $\bar{X}$ & $\mathbf{S}$ & $\mathbf{s d}$ & $\mathbf{t}$ & $\mathbf{p}$ \\
\hline \multirow{2}{*}{ CBPTS } & Experimental & 20 & 19.85 & 6.60 & \multirow{2}{*}{38} & $-2,313$ & $.026^{*}$ \\
\cline { 2 - 5 } & Control & 20 & 22.80 & 3.83 & & & \\
\hline
\end{tabular}

$\overline{\mathrm{p}<.05}$

Table 1; pretest score averages of children in the experimental and control groups Analyzing obtained from "Creative Behavior and Personality Traits Scale" seem to be $\bar{X}=19.85$ in experimental group, and $\bar{X}=22.80$ in the control group. According to this result, it has been 
Kaytez, N., \& Güngör Aytar, A. (2016). Analysis of the Effect of Scamper Education Program on five-year-old children's creativity. Journal of Human Sciences, 13(3), NNN-NNN. doi:10.14687/jhs.v13i3.4037

determined that there is a significant difference in favor of control group between pretest score averages of children in the experimental and control groups $(\mathrm{t}(38)=-2.313 ; \mathrm{p}<.05)$.

Table 2. Averages and Standards Deviation Values of Posttest Scores of Children in the Experimental and Control Groups Adjusted as per Scores Obtained from Creative Behavior and Personality Traits Scale

\begin{tabular}{lcccccccc}
\hline \multirow{2}{*}{ Group } & \multicolumn{3}{c}{ Pretest } & \multicolumn{3}{c}{ Posttest } & \multicolumn{3}{c}{ Adjusted Average } \\
\cline { 2 - 9 } & $\mathrm{n}$ & $\overline{\mathrm{X}}$ & $\mathrm{S}$ & $\mathrm{n}$ & $\overline{\mathrm{X}}$ & $\mathrm{S}$ & $\mathrm{n}$ & $\overline{\mathrm{X}}$ \\
\cline { 2 - 9 } Experimental & 20 & 19.85 & 6.60 & 20 & 26.65 & 5.86 & 20 & 25.31 \\
\hline Control & 20 & 22.80 & 3.83 & 20 & 20.70 & 4.00 & 20 & 19.03 \\
\hline
\end{tabular}

According to Table 2, it has been identified that pretest score average of children in the experimental group is $\bar{X}=19.85$, posttest score average is $\bar{X}=26.65$, pretest score average of children in the control group is $\bar{X}=22.80$ and posttest score average is $\bar{X}=20.70$. Analyzing posttest scores adjusted as per pretest scores of groups, it can be seen that score average of children in the experimental group is $\bar{X}=25.31$ and score average of children in the control group is $\bar{X}=19.03$, score averages of children in the experimental group is higher than those of children in the control group.

Table 3. ANCOVA Results for Scores Achieved by Children in Experimental and Control Group from Creative Behavior and Personality Traits Scale

\begin{tabular}{cccccc}
\hline Source of Variance & DT & Sd & KO & F & p \\
\hline Pretest & 683,713 & 1 & 683,713 & 161,141 & 0,000 \\
\hline Group & 753,630 & 1 & 753,630 & 167,579 & $\mathbf{0 . 0 0 0 *}$ \\
\hline Error & 173,037 & 37 & 4.67 & & . \\
\hline Total & 23731.00 & 40 & & & \\
\hline
\end{tabular}

Analyzing Table 3, it has been identified that there is a statistically significant different between posttest score averages of children in experimental and control groups adjusted as per pretest score averages $[\mathrm{F}(1.37)=161.141, \mathrm{p}<0.001]$. This result indicates that the education offered to the experimental group has a positive effect.

Table 4. T-Test Results on Posttest and Follow-up Score Averages of Children in Experimental Group Obtained from Creative Behavior and Personality Traits Scale

\begin{tabular}{lccccccc}
\hline Scale & Group & $\mathbf{n}$ & $\overline{\mathbf{X}}$ & $\mathbf{S}$ & $\mathbf{s d}$ & $\mathbf{t}$ & $\mathbf{p}$ \\
\hline \multirow{2}{*}{ CBPTS } & Posttest & 20 & 26.65 & 5.86 & \multirow{2}{*}{19} & -.847 & .408 \\
\cline { 2 - 6 } & Follow-up test & 20 & 26.85 & 5.29 & & & \\
\hline
\end{tabular}

According to Table 4, it has been identified that posttest score average of children in the experimental group obtained from Creative Behavior and Personality Traits is $\bar{X}=26.65$, follow-up test average score is $\bar{X}=26.85$ and the different between them is not statistically significant $(\mathrm{t}(19))$ 
Kaytez, N., \& Güngör Aytar, A. (2016). Analysis of the Effect of Scamper Education Program on five-year-old children's creativity. Journal of Human Sciences, 13(3), NNN-NNN. doi:10.14687/jhs.v13i3.4037

$=-.847 ; \mathrm{p}>0.05)$. The fact that there are no significant differences between posttest and follow-up test scores indicates that the effect of applied education continues.

\section{Discussion, Conclusion and Recommendations}

According to research result, it has been determined that Scamper education program is effective in revealing children's creative personality traits and behaviors. Accordingly, in increasing children's scores in the experimental group, activities within scamper education program that promote active participation and aim at featuring creativity are effective.

Preschool period is a period when creative behavior and personality development are at the highest level (Ylldız and Şener, 2007). Therefore, making use of this period effectively is important in terms of educating healthy, happy children with high imagination, creative thinking and personality (Batey and Furnham, 2006). According to Cropley (2003), creative behavior and personality emerge when children are offered with suitable environments. According to Craft (2003), creative behavior has a feature that can be supported and developed, and this ability can be improved with a supportive program to be prepared as per the developmental levels of preschool period. According to Cheung (2010), in each learning environment where creative thinking is used, children's creativity levels improve. According to Brown and Johnson (2008), an educational program supporting creativity can positively affect child's development, especially creative behaviors. According to Pagani, Rubenso and Runca (2003), creative activities offered to children during preschool period support children's skills of creative personality and creative thinking. Other studies conducted on this subject also support these findings. Can-Yaşar (2009), Chronopoulou and Riga (2012), Dziedziewicz, Oledzka and Karwowski (2013), Dziedziewicz, Gajda and Karwowski (2014), Dursun and Ünivar (2011), Erkan, (2005), Garaigordobil and Berrueco (2011), Mirzadie et al. (2009), Şahintürk (2012), Yeh et al. (2006), Zachopoulou et al. (2006) in their studies in which they examined effects of an education program supporting creativity on children's levels of creativity found a significant difference between pretest and posttest score averages of children in experimental and control groups, and they have determined that creativity could be developed with a supportive education. Scamper education program is a program that aims at supporting creativity in children.

According to Alzayad (2014), child must be free and use materials in and around himself/herself without hesitation and fear to reveal instinctive creative personality and behavior. This environment is ideally provided with scamper. Scamper allows children to dream, think differently and product original products (Yağc1, 2012). According to Majid, Girl-Tan and Cheng Soh (2003), children's creativity skills must be support, and activities allowing children to make researches, observations and explorations should be included in education programs. Scamper method improves children's creativity and thinking skills with various question patterns constituting its content and encourages children to make discoveries. Studies on the effect of Internet and scamper method on the development of creativity in children have also determined that scamper method is effective in children's exhibiting creative behaviors. Garaigordobil and Berrueco (2011), in their study examining the effect of game-based education programs on children's creative personality and behavior skills, have found a significant difference between pretest-posttest score averages of children in experimental and control groups. According to this conclusion, creative game-based education offered to children in the experimental group positively affects children's creative personality and behavior patterns. In addition, education program during the preschool period, especially creative game-based trainings integrated with games are quite effective in children's comfortable expression of their feelings and thoughts and exhibiting creative behaviors (Garaigordobil and Berrueco, 2011; Kaufman and Baer, 2005). Scamper, on the other hand, supports child's development and creativity, and contribute to the child significantly (Eberle, 1997). Because activities offered to children in the scamper education program are perceived as game by 
children, in this case, children fondly participate in the education program (Yildiz and Israel, 2001). Lee (2005), in his study examining the relationship between creative thinking and creative personality, found a significant relationship between creative thinking and creative personality, and suggested that creative thinking and personality should be supported. According to Yildiz (2011), questions constituting Scamper content assist in emerging creative thinking and personality inherent in children. In line with these results obtained from the research, following suggestions can be made.

In the research, it has been determined that Scamper Education Program positively affects creativity among children. Integration of Scamper education programs with current programs may significantly contribute to promoting creativity in children. Therefore, educators can give place to studies towards scamper technique while preparing a program. Besides, at the end of scamper applications, assessment can be made to discuss the effect of scamper technique on children. Teachers can be provided with seminars, conferences, in-service trainings etc. regarding creativity, creative thinking in children and especially scamper technique. In teacher training programs, creativity and scamper technique may be described further detailed, in addition to theoretical knowledge, teacher candidates can be guided in applying practical studies. During class practices, it has been observed that children could not move comfortably and there is a need for suitable space to carry out applications such as scamper. Therefore, an environment can be offered that is rich in stimulants and supports learning, where children can move freely, use their senses and make discoveries. School gardens can be arranged for the children to play in a more relaxed way. Besides, researchers may examine short and long-term effects of scamper technique on children's developmental characteristics. Different education programs towards improving creativity among children may be developed or prepared "Scamper Education Program" may be improved in a way to include family participation and effect of this addition may be examined. However, in-service training about scamper technique may be provided to teachers and effect of this training can be examined.

\section{References}

Alyazad, M. N. (2014). The development of creative thinking in preschool teachers: the effects of scamper program. International Journal of Psycho-Educational Sciences, 6(3), 81-87.

Animasahun, R. A. (2014). Effects of scamper creativity training in the prevention of social problems among selected inmates in nigeria prisons. Journal of Emerging Trends in Educational Research and Policy Studies (JETERAPS), 5(3), 301-305.

Aral, N., Köksal Akyol, A,. \& Sı̆̆ırtmaç, A. 2006. Analysis of effects of music education based on Orff teaching on creativity of children in five-six-year-old group. Electronic Journal of Social Sciences, 5(15), 1-9.

Batey, M., \& Furnham, A. (2006). Creativity, intelligence, and personality: a critical review of the scattered literature. Genetic, Social, and General Psychology Monographs, 132(4), 355-429.

Bee, H., \& Boyd. B. (2009). Child Developmental Psychology. Okan Gündüz (Trans.). İstanbul: Kaknüs.

Bilhan, D. Ş. (2007). Creativity and change in early childhood. Uluda $\breve{g}$ University Faculty of Educational Sciences Journal, 20(2), 267-282.

Brown, J., \& Johnson, S. (2008). Childrearing and child participation in Jamaican families. International Journal of Early Years Education, 16, 31-40.

Buser, K. J., Buser, J. T., Gladding, T. S. \& Wilkerson, J. (2011). The creative counselor: using the scamper model in counselor training. Journal of Creativity in Mental Health, 6(4); 256-273.

Büyüköztürk, Ş. (2014). Data analysis handbook for social sciences. Ankara: Pegem.

Can Yaşar, M. (2009). Effects of drama education on creative thinking skills of six-year-old children attending kindergarten. PhD Thesis. Ankara University Institute of Sciences, Ankara. 
Kaytez, N., \& Güngör Aytar, A. (2016). Analysis of the Effect of Scamper Education Program on five-year-old children's creativity. Journal of Human Sciences, 13(3), NNN-NNN. doi:10.14687/jhs.v13i3.4037

Chronopoulou, E., \& Riga, V. (2012). The contribution of music and movement activities to creative thinking in pre-school children. Creative Education,.3 (2); 196-204.

Cheung, P. C., \& Lau, S. (2010). Gender differences in the creativity of Hong Kong school children: Comparison by using the new electronic Wallach-Kogan Creativity Tests. Creativity Research Journal, 22(2), 194- 199.

Craft, A. 2003. Creative thinking in the early years of education. Early Years, 23(2), 143-154.

Cropley, A. (2003). Creativity in Education and Learning: A guide for teachers and educators. USA: Psychology.

Çelikler, D. \& Harman, G. (2015). The effect of the SCAMPER technique in raising awareness regarding the collection and utilization of solid waste. Journal of Education and Practice, 6(10), 149-159.

Dziedziewicz, D., Oledzka, D., \& Karwowski, M. (2013). Developing 4- to 6-year-old children's figural creativity using a doodle-book program. Thinking Skills and Creativity, 9; 85-95.

Dziedziewicz, D., Gajda, A., \& Karwowski, M. (2014). Developing children's intercultural competence and creativity. Thinking Skills and Creativity, 13, 32-42.

Dursun, M. A., \& Ünivar, P. (2011). Analysis of opinions of parents and teachers regarding situations affecting creativity during preschool period. Mehmet Akif University Faculty of Educational Sciences Journal, 21, 110 -133.

Eberle, B. (1997). Scamper. Texas: Prufork.

Erkan, H. (2005). Effects of drama and relief studies on creativity of six-year-old cbildren. Master's Thesis. Gazi University Institute of Education Sciences, Ankara.

Gander, M., \& Gardiner, H. (2007). Child and adolescent's development (6. edition) B. Onur (Trans.). Ankara: İmge.

Garaigordobil, M., \& Berrueco, L. (2011). Effects of a play program on creative thinking of preschool children. The Spanish Journal of Psychology, 14(2), 608-618.

Godel, E. (2006). Relationship between parenting and discipline styles and socioeconomic status. M.Sc. thesis, California State University, Long Beach, California.

Hayes, D. (2004). Understanding creativity and its implications for schools. 1mproving schools. SAGE Publications. 7(3), 279-286.

İslim, Ö. F. (2009), Effect of teaching the information and communication technologies course according to scamper technique on students' creative problem solving skills and academic success. Master's Thesis. Gazi University Institute of Education Sciences, Ankara.

Jamali, B., Kazemi, R., and Shahbazi,M.(2012). Effect of sport activities on increasing preschool children's creativity. Management Science, 2, 1975-1980.

Jagiello, J. (2012). Arts-based Creativity for children through scamper tool: facilitating preschool innovation. Canada: The Banff Centre.

Jelena P., Apple C. Y., Toby M. Y. Tong, S. L. (2014). The feasibility of enhancement of knowledge and self-confidence in creativity: A pilot study of a three-hour scamper workshop on secondary students. Thinking Skills and Creativity, 14, 32-40.

Kaufman, J. C., \& Baer, J. (Eds.). (2005). Creativity across domains: Faces of the muse. Hillsdale, NJ: Lawrence Erlbaum Associates.

Kaytez, N. (2015). Investigation of the effect of "Scamper education program" on the creativity of five year old children. PhD Thesis. Gazi University Institute of Education, Ankara.

Lamm, B., \& Keller, H. (2007). Understanding cultural models of parenting: The role of intercultural variation and response style. Journal of Cross-Cultural Psychology, 38(1), 50-57.

Lee, K. H. (2005). The relationship between creative thinking ability and creative personality of preschoolers. International Education Journal, 6(2), 194-199.

Levine, M. (2002). Every child can achieve, mental development and learning differences at school age. Zeliha Babayigit (Trans.), İstanbul: Boyner. 
Kaytez, N., \& Güngör Aytar, A. (2016). Analysis of the Effect of Scamper Education Program on five-year-old children's creativity. Journal of Human Sciences, 13(3), NNN-NNN. doi:10.14687/ihs.v13i3.4037

Majid, D., Girl-Tan, A., \& Cheng Soh, K. (2003). Enhancing children's creativity: an exploratory study on using the internet and scamper as creative writing tools. The Korean Journal of Thinking\& Problem Solving, 13(2), 67-81.

Mirzaie, R. A., Hamidi, F., \& Anaraki, A. (2009). A study on the effect of science activities on fostering creativity in preschool children. Turkısh Scuence Education, 6(3), 81-90.

Moreno, D. P., Yang, M. C., \& Wood, K. L. (2014). Design creativity for every design problem: a designby-analogy approach. Design Computing and Cognition, 14; 1-10.

Osborn, A. (1993). Applied imagination. creative education foundation. Sternberg, R. J. (Ed.). The nature of creativity. Cambridge, Mass: Cambridge University.

Pagani, L. Rubenson, D., \& Runco, M. A. (2003). The impact of junior kindergarten on behaviour in elementary school children. Internationel Journal of Behavioral Devolopment, 27(5), 423- 427.

Rein, R. P. \& Rein, R. (2000). How can you improve your child's skills and abilities? S. Göktan(Trans.). İstanbul: Ya-pa.

Şahintürk, Ö. (2012). Effect of Montessori method on students' creative thinking during preschool period. Master's Thesis. Zonguldak Karaelmas University Institute of Social Sciences, Zonguldak.

Toraman, A., \& Altun, S. (2013). Application of the six thinking hats and scamper techniques on the 7th grade course unit "Human and environment" : an exemplary case study. Mevlana International Journal of Education, 3(4); 166-185.

Yağc1, E. (2012). Directed brainstorming technique: A study on parents' opinions about scamper. Hacettepe University Journal of Education, 48; 485-494.

Yeh, Y. C., \& Yeh, Y. H., Li, M. L., \& Pen, Y. Y. (2006). An action research in employing creative drama instruction to improve preschoolers' creativity. Journal of Taiwan Normal University Education, 51, 1-27.

Yıldız, V. \& Israel, E. (2001). A way to develop creativity:scamper. Yaşadıkça Eğitim, 74; 53-55.

Yildı, V. (2011). Different thinking activities (scamper). Ankara: Kök.

Yıldız, F. Ü., \& Şener T. (2007). Creativity education in preschool period and preparing materiel for use in activities. Ankara: Nobel.

Zachopoulou, E., \& Trevlas, E., \& Konstadinidou, E. (2006). The design and implementation of a physical education program to promote children's creativity in the early years. International Journal of Early Years Education, 14, 279-294. 